\title{
Developmental changes in the protein and mRNA content of a p115/transcytosis-associated protein in the bovine mammary gland
}

\author{
A Watanabe, I Uchida, K Kadota and N Katoh ${ }^{\mathbf{1}}$ \\ Hokkaido Research Station, National Institute of Animal Health, 4 Hitsujigaoka, Sapporo 062-0045, Japan \\ ${ }^{1}$ The Department of Systematic Diagnosis, National Institute of Animal Health, 3-1-1 Kannondai, Tsukuba 305-0856, Japan \\ (Requests for offprints should be addressed to A Watanabe; Email: awata@affrc.go.jp)
}

\begin{abstract}
We measured the amounts of a vesicular transport factor, p115/transcytosis-associated protein (p115/TAP) and its mRNA, in mammary glands from cows in which lactation was induced hormonally. The highest level of p115/TAP mRNA, determined by Northern blotting, was detected in the developing stage. In contrast to the mRNA level, the amount of protein, determined by immunoblot analysis using anti-p115/TAP antibodies raised against a p115/TAP-derived recombinant fusion protein, was higher during the lactating stages than at other times. Immunohistochemical study showed that p115/TAP was predominantly localized in mammary epithelial cells. The
\end{abstract}

p115/TAP was also detected in tissues other than the mammary gland but, in contrast to the situation in the mammary gland, the protein and its mRNA levels in those tissues were independent of the stage of lactation. The increased level of $\mathrm{p} 115 / \mathrm{TAP}$ mRNA during the developing stage and the maintenance of $\mathrm{p} 115 / \mathrm{TAP}$ protein during lactation suggest that the synthesis of $\mathrm{p} 115 / \mathrm{TAP}$ is regulated during mammary development and differentiation, and also that the protein is involved in a function related to lactation.

Journal of Endocrinology (2000) 166, 319-327

\section{Introduction}

Along with the reproductive cycle of mammals, the mammary gland undergoes a cycle of development, differentiation and involution. In these processes, mammary function and structure are regulated by multiple hormones and growth factors (Topper \& Freeman 1980, Collier et al. 1993, Flint \& Knight 1997). During mammary development, the organelles related to synthesis, maturation and transport of milk constituents proliferate and develop in alveolar epithelial cells (Saacke \& Heald 1974). Lactating mammary epithelial cells contain abundant endoplasmic reticula, well-developed Golgi apparatuses and numerous secretory vesicles (Wooding 1977). Milk proteins are transported via bilayer membrane-bounded vesicles from the endoplasmic reticulum to the Golgi apparatus, to a secretory vesicle, to the apical membrane and are then secreted into the alveolar lumen by exocytosis (Nickerson \& Akers 1984).

Vesicular transport factor $\mathrm{p} 115 /$ transcytosis-associated protein (p115/TAP) is a cytosolic and peripheral Golgi membrane protein required for intra-Golgi vesicular transport and transcytotic membrane transport (Waters et al. 1992, Barroso et al. 1995). This protein is also considered to be involved in exocytotic vesicle transport (Bajjalieh \& Scheller 1995). In vesicular transport, p115/TAP is suggested to mediate the docking of transport vesicles with their acceptor membrane (Nakamura et al. 1997). p115/TAP is also a protein that binds to cytidine 5'-triphosphate:phosphocholine cytidylyltransferase (CT), a rate-limiting enzyme in the synthesis of phosphatidylcholine (PC), and increases CT activity by mediating the binding of the enzyme to traffic vesicles (Feldman \& Weinhold 1998).

Because of its relevance to various types of vesicular transport, $\mathrm{p} 115 / \mathrm{TAP}$ is postulated to be involved in the regulation of mammary development and functions. The regulation of expression of $\mathrm{p} 115 / \mathrm{TAP}$ during mammary development and differentiation, however, has not yet been demonstrated. In the present study, the mRNA and protein content of $\mathrm{p} 115 / \mathrm{TAP}$ was examined in mammary glands from cows in which lactation was induced hormonally. Expression levels of p115/TAP mRNA were examined by Northern blot analysis or reversetranscription polymerase chain reaction (RT-PCR). The protein content was determined by immunoblotting using a specific antiserum to bovine p115/TAP prepared by immunizing rabbits with a recombinant protein corresponding to a part of p115/TAP. The distribution of this protein in mammary tissue was examined immunohistochemically by the indirect fluorescent antibody (IFA) method. The mRNA and protein content was also 


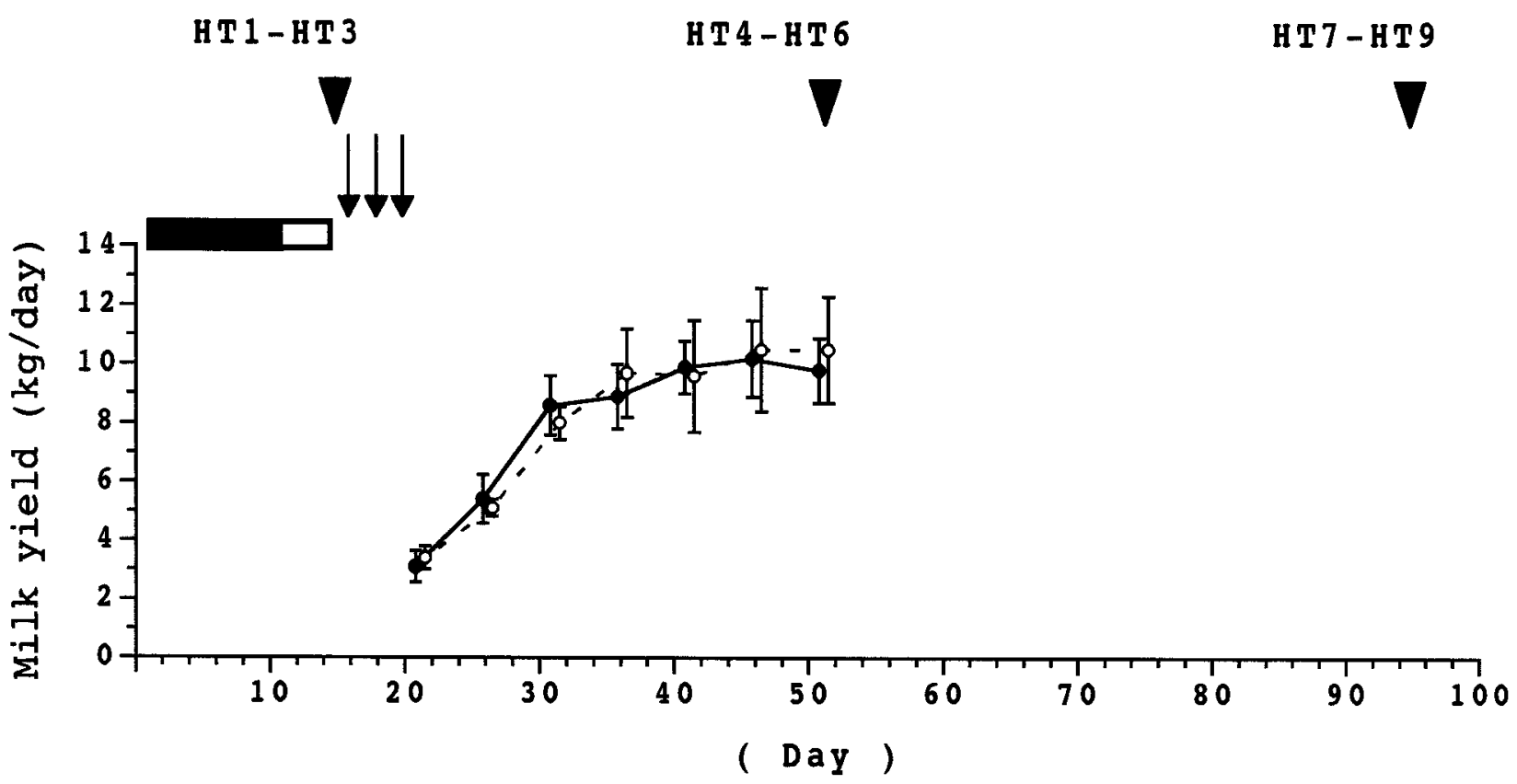

Figure 1 Hormone treatments, sampling schedule and milk yields during the course of hormonally induced lactation. Daily injections of estradiol-17ß (at $75 \mu \mathrm{g} / \mathrm{kg}$ ) and progesterone (at $300 \mu \mathrm{g} / \mathrm{kg}$ ) in ethanol were given subcutaneously to nine cows (HT1-HT9) from day 1 to day 10 ( $\mathbf{\square})$; this was followed by daily injections of estradiol- $17 \beta$ (at $75 \mu \mathrm{g} / \mathrm{kg}$ ) for 4 days $(\square)$. Reserpine $(6 \mu \mathrm{g} / \mathrm{kg} / \mathrm{day})$ was administered to six cows (HT4-HT9) on days 16, 18 and 20 (arrow). Twice-daily milking was started on day 21 and continued to day 51. Milk yields of cows HT4-HT6 $(\mathrm{O})$ and HT7-HT9 $(\bullet)$ are indicated. Cows in the developing stage (HT1-HT3), the lactating stage (HT4-HT6) and the involuting stage (HT7-HT9) were sacrified at days 15, 51 and 95 (arrowheads) respectively. Mammary tissues from the resting stage were obtained from three cows $(\mathrm{N} 1-\mathrm{N} 3)$.

evaluated in tissues other than the mammary gland to determine whether the changes induced by hormonal treatment were specific to this tissue.

\section{Materials and Methods}

\section{Materials}

Diethylaminoethyl (DEAE) Sephacel, Q Sepharose FF, heparin Sepharose CL-6B, protein A Sepharose CL$4 \mathrm{~B}$, cyanogen bromide $(\mathrm{CNBr})$-activated Sepharose $4 \mathrm{~B}$, oligo(dT)-cellulose, $\left[\alpha-{ }^{32} \mathrm{P}\right] \mathrm{dCTP}(\sim 110 \mathrm{TBq} / \mathrm{mmol})$, a DNA labeling kit (the Rediprime DNA labeling system) and enhanced chemiluminescence (ECL) Western blotting detection reagents were purchased from Amersham Pharmacia Biotech (Little Chalfont, UK). The Bio-Gel HT was from Bio-Rad Laboratories (Hercules, CA, USA), the One Step RNA PCR Kit was from Takara Shuzo Co. (Otsu, Japan) and the Original TA Cloning Kit was purchased from the Invitrogen Co. (Carlsbad, CA, USA). Plasmid vector pQE-30, competent M15[pREP4] cells, Ni-NTA agarose and a mouse anti-tag sequence expressed from pQE-30 (RGSHHHH) immunoglobulin (Ig) $\mathrm{G}_{1}$ (RGS-His antibody) were from QIAGEN GmbH (Hilden, Germany). Horseradish peroxidase-conjugated antibodies to rabbit $\operatorname{IgG}$ or mouse $\operatorname{IgG}$, and fluorescein isothiocyanate (FITC)-conjugated donkey anti-rabbit IgG were obtained from Jackson ImmunoResearch Laboratories (West Grove, PA, USA). All other reagents were of analytical grade or higher.

\section{Hormonally induced lactation and tissue preparation}

Lactation was hormonally induced in nine Holstein cows, HT1-HT9 (5 or 6 years old) in which more than 1 year had elapsed since the last milking (Johke et al. 1980). The protocols for hormone treatments, sampling schedules and milk yields are shown in Fig. 1. The lactating and involuting groups were divided to minimize the differences in the milk yields of the two groups. Tissues during the resting stage were obtained from three cows (N1-N3) for which more than 1 year had elapsed since the last milking. These cows, N1-N3, did not receive hormone treatment. Testes were obtained from two bullocks (2 years old).

Tissues were quickly excised and frozen in liquid nitrogen. Cytoplasmic extracts and nuclear fractions were prepared as described previously (Katoh et al. 1993). For histological examination, mammary glands were embedded in O.C.T. compound (Miles Inc., Elkhart, IN, 
USA) and quickly frozen in $n$-hexane cooled in dry ice. All preparations were stored at $-80{ }^{\circ} \mathrm{C}$ until used.

\section{General protocols}

Protein concentrations were determined according to Bradford (1976), using bovine $\gamma$-globulin as the standard. Concentrations of DNA and RNA in tissue homogenates were measured by the methods of Burton (1956) and Schneider (1957) respectively. Total RNA was prepared from tissue by the acid guanidinium thiocyanate-phenolchloroform extraction method (Chomczynski \& Sacchi 1987). Standard methods were used for molecular cloning and genetic analysis (Sambrook et al. 1989). Data are presented as means \pm S.E.M. values and significance was analyzed by one-factor ANOVA and Scheffe's F-test.

\section{RT-PCR, plasmid construction and expression of recombinant protein}

A pair of oligonucleotide primers (sense primer, $5^{\prime}-\mathrm{GCg}$ gatccGTGACTCACTACAAAAATATGATT-3'; antisense primer, $5^{\prime}$-gtcgacGTTACAATATAGTCTCTAT CATTC-3') were synthesized according to the nucleotide sequence of bovine p115/TAP (Sapperstein et al. 1995). Extra sequences were included to introduce restriction sites (lower-case letters) BamHI and SalI respectively. Continuous RT-PCR was performed with the One Step RNA PCR Kit and the pair of primers. The RT-PCR product was inserted into pCR2.1 and designated pCR-TAP1n6 using the Original TA Cloning Kit, then subcloned into expression vector $\mathrm{pQE}-30$ at BamHI and SalI sites and designated pQE-TAP1G. Competent M15[pREP4] cells were transformed with pQE-TAP1G. The recombinant protein, designated p115 $\mathrm{HtCt}$, was expressed in the transformant and purified by chromatography on Ni-NTA agarose according to the manufacturer's instructions.

The nucleotide sequence of the cloned fragment was verified by using an ABI PRISM 310 Genetic Analyzer (Applied Biosystems, Foster City, CA, USA) with the recommended sequencing kit.

\section{Preparation of antibodies}

Antiserum to $\mathrm{p} 115 \mathrm{HtCt}$ was raised in rabbits as described previously (Watanabe et al. 1997), using $100 \mu \mathrm{g}$ p 115 $\mathrm{HtCt}$ in each initial or booster immunization. The IgG fraction was prepared from the antiserum by protein A Sepharose chromatography. Anti-p115 HtCt IgGSepharose 4B (3 mg/ml gel) was prepared according to the instruction manual. p115 HtCt-Sepharose 4B $(5 \mathrm{mg} / \mathrm{ml}$ gel) was used for absorption of antibodies to p115/TAP.

\section{Purification of bovine mammary p115/TAP}

Bovine p115/TAP was partially purified from a lactating mammary gland by sequential chromatography on DEAE
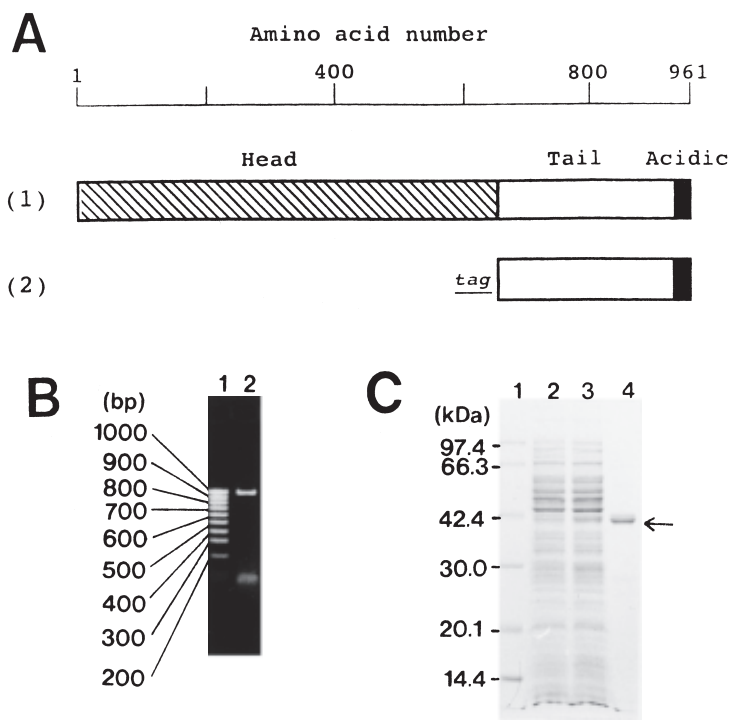

Figure 2 Construction, expression and purification of a recombinant protein (p115 HtCt). (A) Schematic illustration of the structure of bovine p115/TAP (Sapperstein et al. 1995). p115/TAP, which consists of a head (hatched box), a tail ( $\square$ ) and an acidic domain ( $\mathbf{\square})$, is shown (A, 1). A schematic drawing of recombinant protein $\mathrm{p} 115 \mathrm{HtCt}$ containing the tail and the acidic domain of p115/TAP with an N-terminal tag is shown (A, 2). (B) RT-PCR amplification of part of the p115/TAP gene. Total RNA from a developing mammary gland was subjected to continuous RT-PCR. One microgram RNA was used for $50 \mu \mathrm{l}$ reaction mixture. Reaction conditions were as follows: $50{ }^{\circ} \mathrm{C}$ for $30 \mathrm{~min}, 94{ }^{\circ} \mathrm{C}$ for 2 min, 30 cycles of $94{ }^{\circ} \mathrm{C}$ for $40 \mathrm{~s}, 50{ }^{\circ} \mathrm{C}$ for $1 \mathrm{~min}, 72{ }^{\circ} \mathrm{C}$ for $2 \mathrm{~min}$ and then a step to ensure extension $\left(72{ }^{\circ} \mathrm{C}\right.$ for $8 \mathrm{~min}$ ). Molecular size markers (lane 1 ) and the amplified products (lane 2) were analyzed in $1.7 \%$ agarose gel. DNA bands were stained with ethidium bromide. (C) SDS-PAGE analysis of p115 HtCt expressed in Escherichia coli strain M15[pREP4]. Molecular weight marker proteins (lane 1), $15 \mu \mathrm{g}$ proteins of bacterial cell lysate before (lane 2 ) or $3 \mathrm{~h}$ after (lane 3 ) isopropyl- $\beta$-D-thiogalactoside had been added, and $1 \mu \mathrm{g}$ p115 HtCt purified by Ni-NTA agarose chromatography (lane 4 ) were separated in a $12 \%$ gel and stained with Coomassie brilliant blue R-250.

Sephacel, Q Sepharose and Bio-Gel HT as described by Waters et al. (1992). Fractions from the Bio-Gel HT column that were rich in p115/TAP (determined by immunoblot analysis) were pooled, dialyzed against $20 \mathrm{mM}$ Tris- $\mathrm{HCl}(\mathrm{pH} 7 \cdot 4)$ and $1 \mathrm{mM}$ EDTA and applied to a heparin Sepharose CL-6B column equilibrated with the same buffer solution. The pass-through fractions were pooled (heparin pool). The heparin pool was next applied to an immunoaffinity column packed with anti-p115 HtCt IgG-Sepharose 4B.

\section{Electrophoresis, immunoblotting and Northern blotting}

Protein samples were separated by SDS-PAGE. Separated proteins were transferred to a polyvinylidene difluoride membrane. Immunostaining of the membrane was carried 

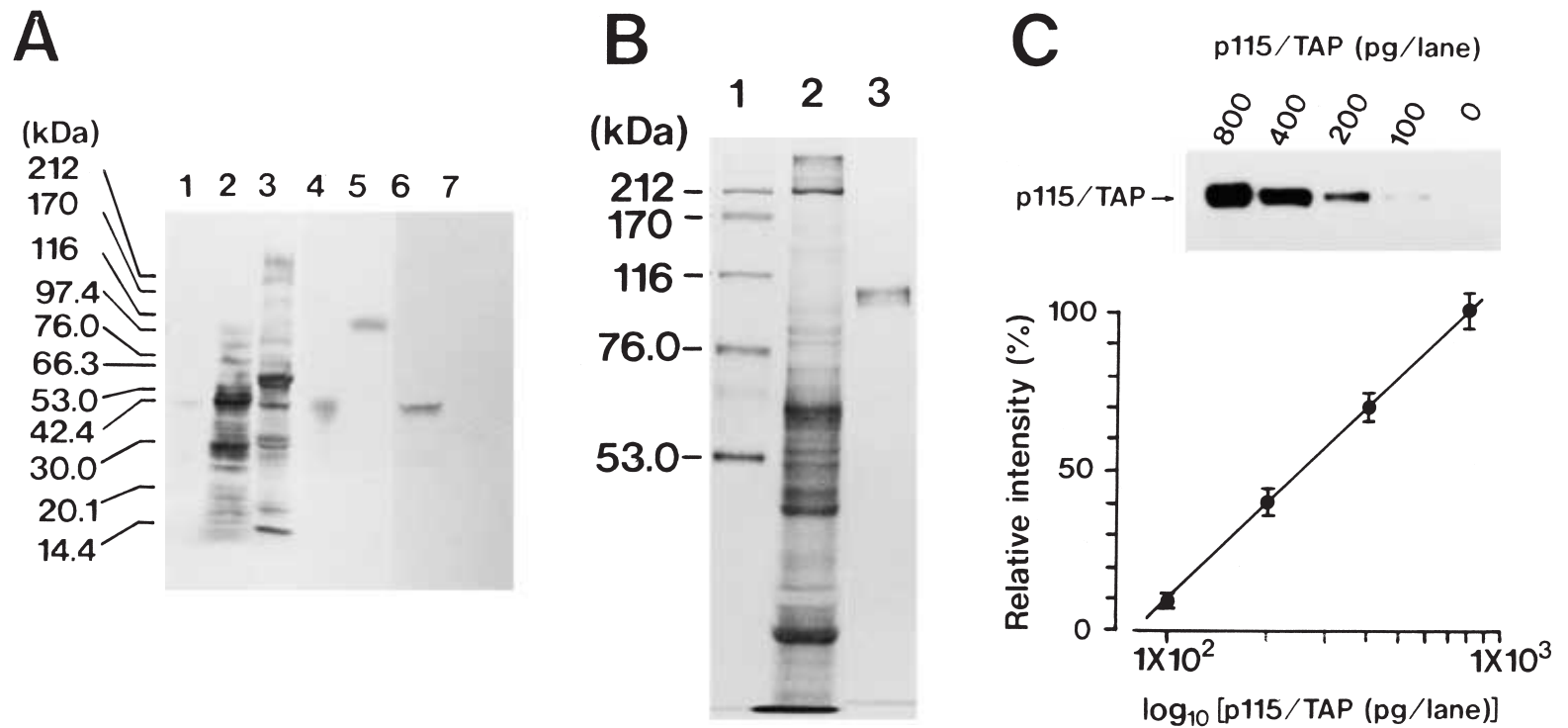

Figure 3 Detection, purification and quantification of p115/TAP. (A) Specificity of anti-p115/TAP antibody in immunoblotting. Purified p115 HtCt (lane 1), proteins of bacterial cell lysate in which p115 HtCt was expressed (15 $\mu$ g for lane 2 and $0.5 \mu \mathrm{g}$ for lanes 4 and 6), and $15 \mu \mathrm{g}$ cytoplasmic proteins of lactating mammary tissue (lanes 3, 5 and 7) were separated by SDS-PAGE in a 5-20\% gradient gel and then transferred to a polyvinylidene difluoride membrane. Proteins in lanes 1-3 were stained with Coomassie brilliant blue R-250. Lanes 4-7 were immunostained. For lanes 4 and 5, rabbit anti-p115 HtCt serum was used as the first antibody. RGS-His antibody was used for detection of the tag portion of the recombinant protein (lanes 6 and 7). The positions of molecular weight marker proteins are on the left. (B) Purification and quantification of p115/TAP. Molecular weight marker proteins (lane 1), $1 \mu \mathrm{g}$ proteins in the cytosol (lane 2) and $0.03 \mu \mathrm{g}$ p115/TAP purified by anti-p115 HtCt IgG-Sepharose (lane 3 ) were separated by SDS-PAGE $(7 \cdot 5 \%$ gel) and stained with silver. (C) Quantification of p115/TAP protein. Different amounts of p115/TAP were subjected to immunoblot analysis (upper panel) in triplicate, and bands detected were scanned with a densitometer (CS-9300PC; Shimadzu Co., Kyoto, Japan) to obtain a standard curve (lower panel).

out essentially as reported in a previous paper (Watanabe et al. 1997). Immunoreactive bands were detected by use of ECL reagents.

RNA samples were electrophoresed and blotted onto a nylon membrane, in a denatured condition (Sambrook et al. 1989). Following prehybridization, the membrane was hybridized with a randomly primed and $[\alpha-$ $\left.{ }^{32} \mathrm{P}\right] \mathrm{dCTP}-\mathrm{labeled}$ cDNA probe from the fragment cloned in pCR-TAP1n6. The hybridized radioactivity was detected by autoradiography. The ratio of poly(A)+ RNA to total RNA was estimated by hybridization to $\operatorname{poly}(\mathrm{U})$ (Catelli et al. 1989). Poly(A)+ RNA, prepared from mammary total RNA by chromatography on oligo(dT)cellulose, was used as the standard in this assay.

\section{Immunohistochemistry}

Frozen samples were sectioned, air-dried and fixed with cold acetone $\left(-20^{\circ} \mathrm{C}\right)$ for $10 \mathrm{~min}$. Each section was stained by the IFA method, probing with rabbit anti-p115 $\mathrm{HtCt}$ serum followed by FITC-conjugated anti-rabbit IgG. Other sections from each sample were also stained with hematoxylin and eosin (HE).

\section{Results}

In the RT-PCR, a DNA fragment (986 bp) including the coding region for the tail and the acidic domain of p115/TAP (Fig. 2A) was amplified from a total RNA sample of a bovine mammary gland (Fig. 2B). A $40 \mathrm{kDa}$ recombinant protein, p115 $\mathrm{HtCt}$, was expressed in M15[pREP4] cells transformed with pQE-TAP1G and was purified by Ni-NTA agarose chromatography (Fig. 2C).

The specificity of anti-p115 HtCt serum was examined by immunoblot analysis. Rabbit anti-p115 HtCt serum stained $\mathrm{p} 115 / \mathrm{TAP}$ at $108 \mathrm{kDa}$ in the cytoplasmic extract of bovine mammary gland and p115 HtCt at $40 \mathrm{kDa}$ (Fig. 3A). The antiserum preabsorbed with p115 HtCtSepharose did not react with any protein bands in the cytoplasmic extract (data not shown). The RGS-His antibody reacted with p115 $\mathrm{HtCt}$, but not with any protein bands in mammary cytoplasm. The p115/TAP was not detected in the nuclear fraction of any of the samples examined (data not shown).

Quantitative immunoblotting was performed using rabbit anti-p115 HtCt serum with purified p115/TAP as 


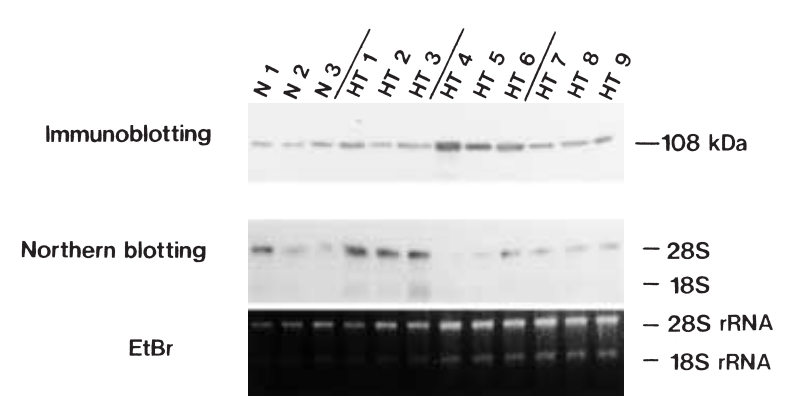

Figure 4 Immunoblot analysis of p115/TAP and Northern blot analysis of specific mRNA during the course of hormonally induced lactation. For immunoblotting using rabbit anti-p115 HtCt serum, $15 \mu \mathrm{g}$ mammary cytoplasmic proteins from each cow (N1-N3 and HT1-HT9) were analyzed (upper panel). Total RNA $(33 \mu \mathrm{g})$ from each cow was analyzed by Northern blotting (middle panel). The electrophoretograms ( $1 \cdot 4 \%$ agarose gel) of RNA samples stained with ethidium bromide $(\mathrm{EtBr})$ are also displayed (lower panel).

the standard (Fig. 3B and C). By using the standard curve, p115/TAP was calculated to be purified from mammary gland cytosol at $>95 \%$ purity with $2 \cdot 3 \%$ recovery.

Lactation was hormonally induced to examine whether p115/TAP was developmentally regulated at protein and gene expression levels. The poly(A)+ RNA contents of total RNA isolated from mammary tissue were $1.55 \pm 0.11 \mu \mathrm{g} / \mathrm{mg}$ for the resting state $(\mathrm{N} 1-\mathrm{N} 3)$, $1.72 \pm 0.05 \mu \mathrm{g} / \mathrm{mg}$ for the developing state (HT1-HT3), $2 \cdot 21 \pm 0 \cdot 13 \mu \mathrm{g} / \mathrm{mg}$ for the lactating state (HT4-HT6) and $1.63 \pm 0.06 \mu \mathrm{g} / \mathrm{mg}$ for the involuting state (HT7HT9). The differences between the lactating and other groups were significant $(P<0 \cdot 05)$.

The amounts of mRNA for $\mathrm{p} 115 / \mathrm{TAP}$ were estimated in mammary glands from cows N1-N3 and HT1-HT9 by using a cDNA probe (Figs 4 and 5). The highest amount of mRNA was detected in developing tissues when the mRNA level was normalized to both total RNA and DNA, although the ratio of poly(A)+ RNA to total RNA in developing mammary glands remained essentially unchanged from that in the resting stage. This showed that p115/TAP mRNA selectively accumulated in developing mammary tissue. The p115/TAP mRNA level in lactating tissue was the lowest on the basis of total RNA content, whereas it was the highest next to the level of the developing gland on the basis of DNA content. This low rate of $\mathrm{p} 115 / \mathrm{TAP} \mathrm{mRNA}$ relative to total RNA may have been due to dilution of p115/TAP mRNA by the milk-protein mRNAs, which constitute the majority of the mRNA during lactation (Rosen et al. 1975, Catelli et al. 1989). In involuting tissue, the p115/TAP mRNA level per cell (on the basis of DNA content) was lower than that in lactating tissue.

The amounts of $\mathrm{p} 115 / \mathrm{TAP}$ protein were measured in mammary glands from cows N1-N3 and HT1-HT9 by quantitative immunoblot analysis (Fig. 4 and Table 1). The

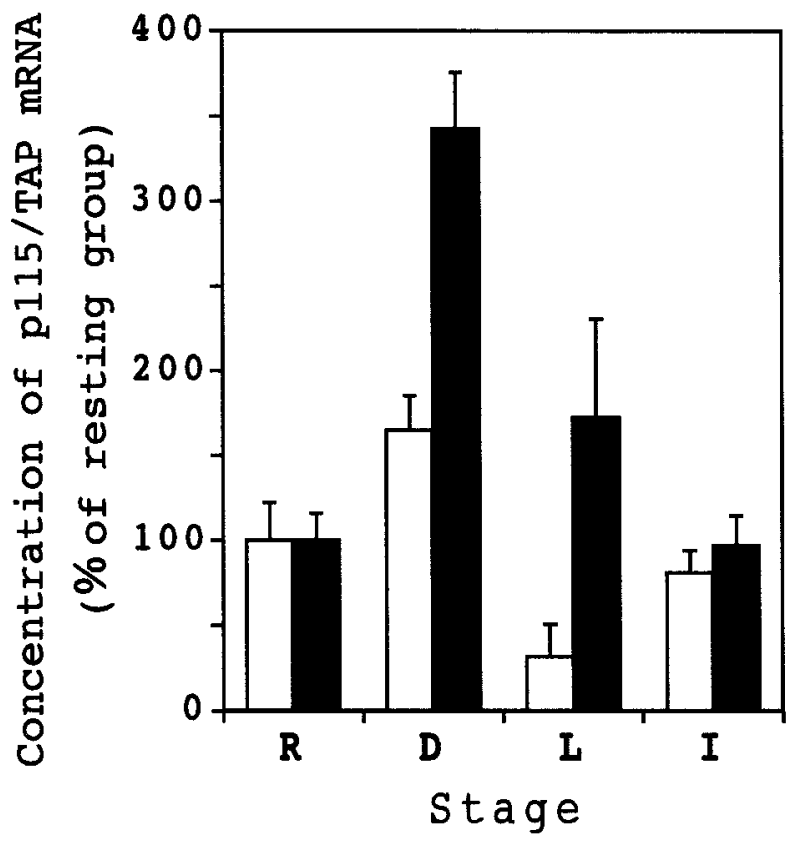

Figure 5 Estimation of the amount of p115/TAP mRNA in mammary tissues from various developmental stages. Mammary tissues ( $n=3$ for each stage) from resting (R), developing (D), lactating (L) and involuting (I) stages were analyzed for p115/TAP mRNA as described for Fig. 4. For quantification, the autoradiographs were scanned by densitometry. The $100 \%$ control value is the mean of the scanning intensities observed in the resting stage. Relative concentrations of $\mathrm{p} 115 / \mathrm{TAP}$ mRNA normalized to total RNA $(\square)$ and DNA $(\square)$ are shown.

p115/TAP content in developing glands (HT1-HT3) appeared to be higher than that in resting glands (N1-N3), but the differences did not reach statistical significance. In the developing tissues, accumulation of p115/TAP would be still be progressing towards lactation. The p115/TAP protein content was significantly higher in the lactating group (HT4-HT6) than in the other groups. The decrease in mammary p115/TAP content from the lactating to the resting stage may be attributable to decreased synthesis of the protein during the involuting stage.

Table 1 Concentrations of p115/TAP in cytoplasm from mammary glands of cows in various developmental stages during the course of hormonally-induced lactation. Values are means \pm S.E.M.

$\begin{array}{ll}\mathbf{n} & \begin{array}{l}\text { Concentration } \\ (\mu \mathrm{g} / \mathrm{mg} \text { prote })\end{array} \\ 3 & 0 \cdot 74 \pm 0 \cdot 06 \\ 3 & 1 \cdot 14 \pm 0 \cdot 21 \\ 3 & 2 \cdot 68 \pm 0 \cdot 28^{*} \\ 3 & 1 \cdot 40 \pm 0 \cdot 10\end{array}$

${ }^{*}$ Higher than values of resting $(P<0 \cdot 001)$, developing $(P<0 \cdot 005)$ and involuting stage $(P<0 \cdot 05)$. 


\section{[Stages]}

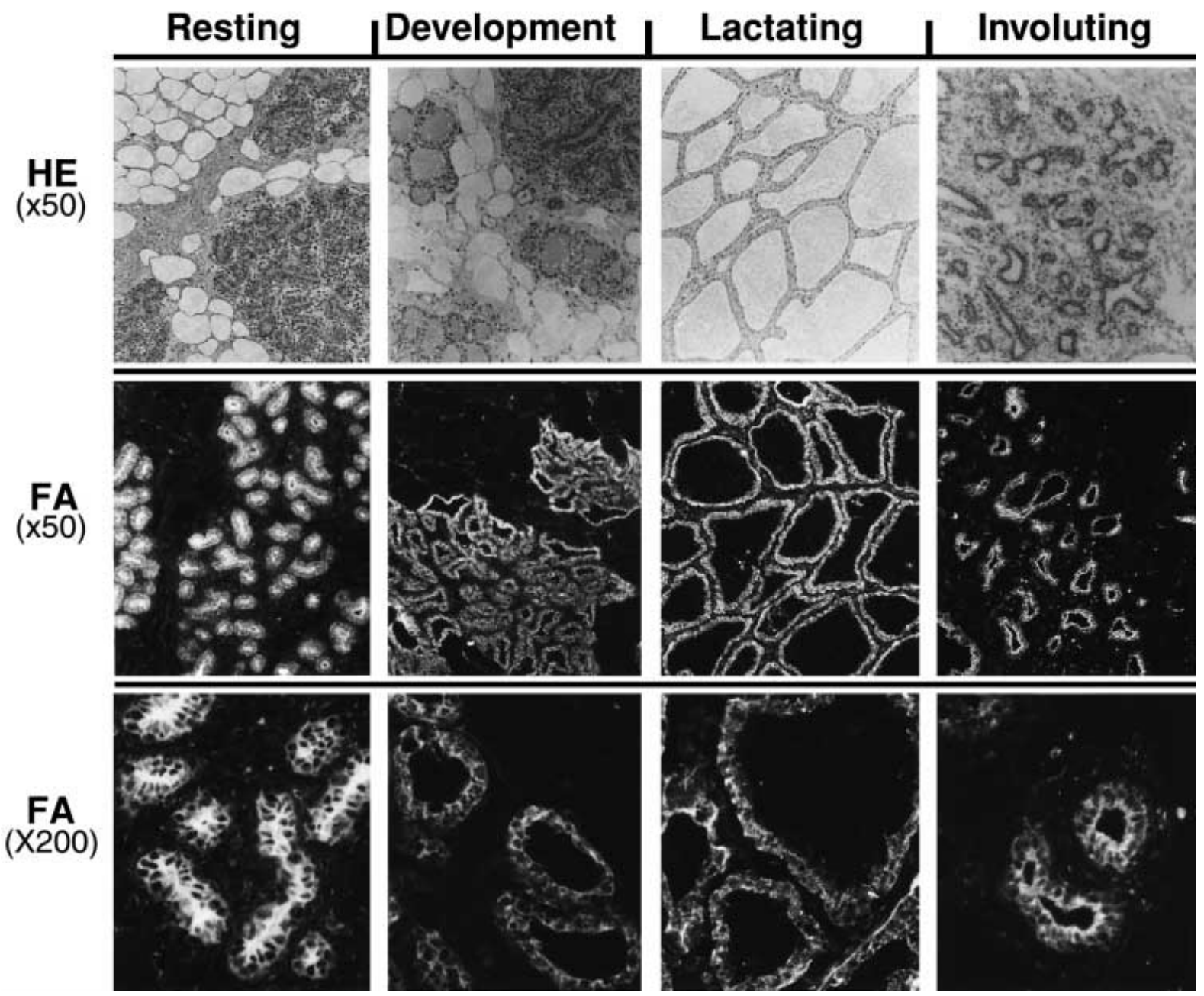

Figure 6 Immunohistochemical localization of p115/TAP in mammary tissue during the course of hormonally induced lactation. Mammary tissues from cows in the resting, the developing, the lactating and the involuting stages were stained with HE or by IFA. The magnifications are indicated in parentheses.

The localization of p115/TAP in mammary glands was examined immunohistochemically. The p115/TAP was shown to be predominantly localized in the cytoplasm of mammary epithelial cells at all stages of lactation (Fig. 6).

In tissues other than mammary gland, p115/TAP mRNA and protein levels were also examined. The p115/TAP mRNA and protein levels varied with the tissue (Fig. 7A). Tissues from brain, adrenal gland, lung, salivary gland and testis were rich in $\mathrm{p} 115 / \mathrm{TAP}$, as was the mammary gland. Extremely low levels of p115/TAP were detected in the thyroid, adipose tissue, the duodenum and the jejunoileum. These four tissues also showed undetectable levels of the RT-PCR product. In contrast to the levels in mammary-gland tissue, p115/TAP mRNA levels in other tissues, such as heart and abomasum (Fig. 7B), as well as protein content (data not shown), were not associated with different stages of lactation (Fig. 7B).

\section{Discussion}

In the present study, a model of steroid-primed hormonally induced lactation was used to examine whether mammary p115/TAP was developmentally regulated at protein and gene expression levels. The present study showed that $\mathrm{p} 115 / \mathrm{TAP}$ was regulated during mammary development and differentiation at both protein and mRNA expression levels, and also that the regulation was observed in mammary-gland tissue, but not in other tissues. In mammary glands, p115/TAP was predominantly 


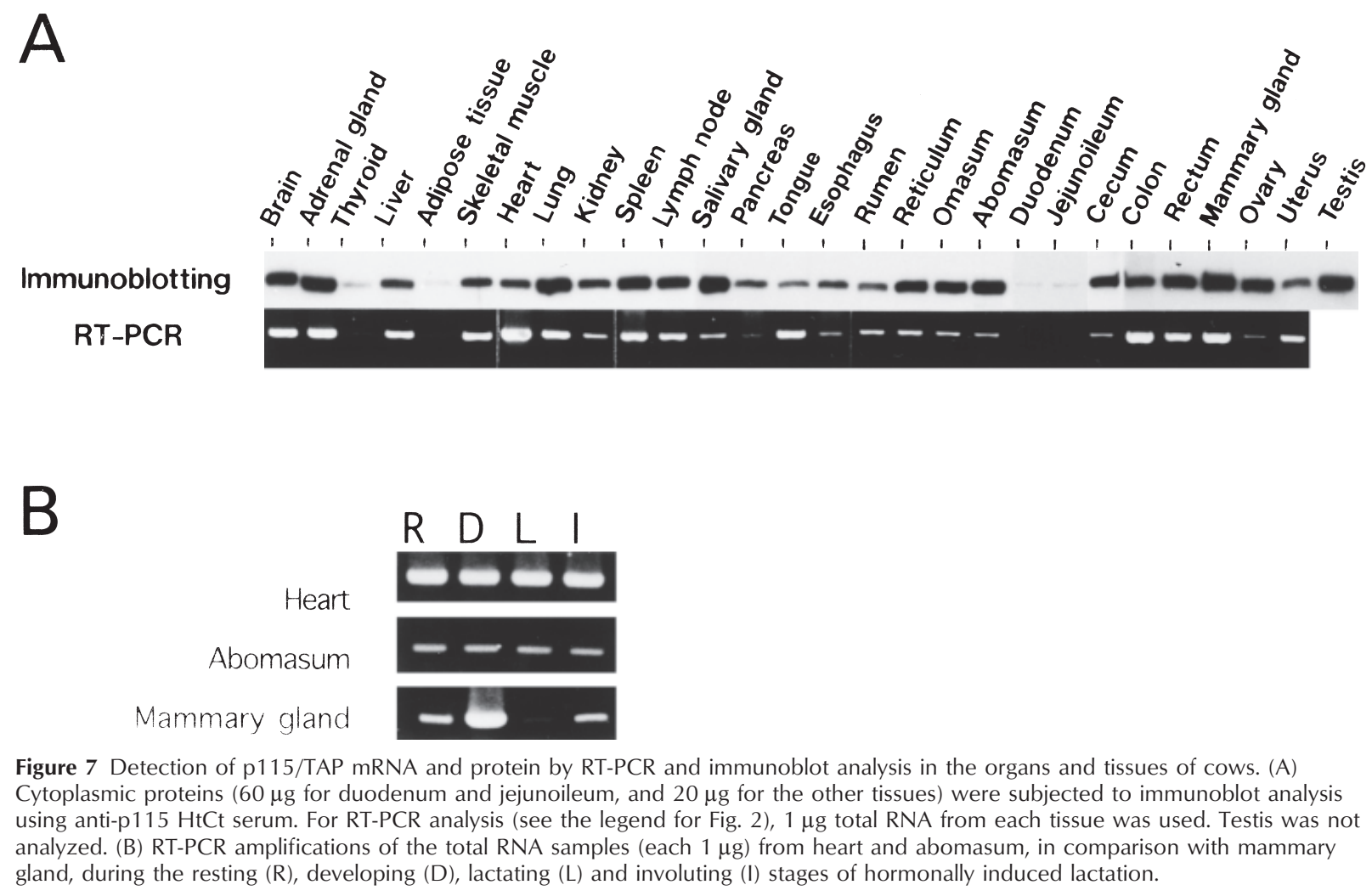

localized in mammary epithelial cells at all stages of lactation, suggesting that $\mathrm{p} 115 / \mathrm{TAP}$ content was regulated in mammary epithelial cells.

Progesterone and estrogen are required for ductal morphogenesis and lobuloalveolar development of the mammary gland during pregnancy (Topper \& Freeman 1980, Forsyth 1983, Silberstein et al. 1994). Estrogen is especially important for priming the lobuloalveolar growth of the mammary gland throughout gestation (Forsyth 1983, Plath et al. 1997). In this study, the significant accumulation of p115/TAP mRNA in the mammary gland was observed following the treatment with estradiol-17 $\beta$ to simulate late pregnancy, suggesting that gene expression of p115/TAP is stimulated in relation to the steroid-dependent growth of the mammary gland. During pregnancy, a family of gene-transcription regulatory factors (CCAAT/enhancer binding proteins) is differentially induced in the mammary gland in a tissue- and a stage-specific manner (Raught et al. 1995). The family of transcription regulatory factors is considered to be involved in the steroid-primed lobuloalveolar development of the mammary gland (Seagroves et al. 1998) and in expression of milk-protein mRNAs (Raught et al. 1995). These factors may be implicated in the steroid-dependent and mammaryspecific increase in p115/TAP mRNA expression during mammary development. In late gestation, the mRNAs of milk proteins begin to accumulate until lactation, when milk proteins are largely synthesized (Rosen et al. 1975, Schanbacher et al. 1993). The p115/TAP mRNA may be also accumulated beforehand to increase the protein content in the lactating mammary gland to support the secretion of milk proteins by vesicular transport.

A higher content of mammary $\mathrm{p} 115 / \mathrm{TAP}$ was found in the lactating stage relative to other stages, and its mRNA level (normalized with DNA content) was higher in the lactating mammary gland than in resting and involuting glands. These results cannot simply be due to the ovarian steroids, because the lactating mammary gland is unable to respond to estrogen and the progesterone receptor is undetectable during lactation (Forsyth 1983, Catelli et al. 1989). The effect of reserpine, which causes a prolonged elevation of the plasma prolactin concentration, would not directly affect the mRNA and protein levels of p115/TAP in the lactating mammary gland, because this effect is transient, continues only for approximately 10 days (Johke et al. 1981) and does not continue to the point at which the lactating tissues were obtained in this study. At present, it is difficult to deduce the mechanism underlying the accumulation of $\mathrm{p} 115 / \mathrm{TAP}$ mRNA and protein in lactating tissue compared with involuting and resting tissue. Mammary lactogenic differentiation is under the control of many hormones and growth factors (Topper \& Freeman 1980, Collier et al. 1993, Flint \& Knight 1997). The effects not only of humoral factors but also of extracellular 
matrix components influence gene expression associated with mammary differentiation (Lelièvre et al. 1996). As for the decreasing concentrations of mammary p115/TAP from lactating to involuting stages, it is also noteworthy that the amounts of endogenous mammary proteases are much lower during lactation than during non-lactating stages (Talhouk et al. 1992). The induction and the maintenance of mammary p115/TAP may be the result of several physiological processes associated with lactation. However, a clearer elucidation of the cellular mechanisms underlying mammary p115/TAP regulation must await further studies.

Various types of vesicular traffic are abundantly present in epithelial cells of the lactating mammary gland (Nickerson \& Akers 1984). Milk proteins are transported via bilayer membrane-bounded vesicles from the endoplasmic reticulum to the Golgi apparatus, to a secretory vesicle, to the plasma membrane and are then secreted into the alveolar lumen by exocytosis (Nickerson \& Akers 1984). Because $\mathrm{p} 115 / \mathrm{TAP}$ mediates the docking of traffic vesicles and acceptor membranes in intra-Golgi transport (Nakamura et al. 1997) and exocytosis (Bajjalieh \& Scheller 1995), the protein increase in the lactating epithelial cells is considered to be involved in the pathway for milk-protein secretion. In addition, p115/TAP would be implicated in vesicular transport to supply membranes for the proliferation, development and maintenance of organelles (Saacke \& Heald 1974, Mather \& Keenan 1983). p115/TAP is also suggested to be implicated in the transcytotic secretion of immunoglobulins across the mammary epithelia (Lascelles et al. 1986), because p115/TAP has been shown to be a factor required for binding of the transcytotic vesicle to its target membrane (Barroso et al. 1995). Milk-lipid droplets are released from the endoplasmic reticulum into cytosol bounded by non-bilayer proteins and polar lipids, including PC, and then secreted (Ghosal et al. 1993). In addition to protein secretion into milk, p115/TAP may also be associated with the formation of milk-lipid droplets, because the protein increases the activity of CT, which is a major regulatory enzyme for PC synthesis (Feldman \& Weinhold 1998).

As expected, p115/TAP was detected immunochemically in all tissues examined because the protein is required for various types of general vesicular transport (Waters et al. 1992, Barroso et al. 1995, Feldman \& Weinhold 1998). The $\mathrm{p} 115 / \mathrm{TAP}$ content, however, varied greatly with the type of tissue. In tissues from the brain and adrenal gland, both of which are rich in p115/TAP, exocytotic release of neural transmitters may involve p115/TAP (Bajjalieh \& Scheller 1995). In the duodenum and the jejunoileum, p115/TAP content was very low and its mRNA was not detected. Although a clear explanation of why so little $\mathrm{p} 115 / \mathrm{TAP}$ is required for these tissues cannot be given at present, this observation may be related to the fact that PC in very low-density lipoprotein secreted from intestinal cells is derived from dietary sources rather than from de novo synthesis (Vance \& Vance 1990).

\section{Acknowledgements}

This work was partly funded by the Ministry of Agriculture, Forestry and Fisheries, Japan (RCP 1999-4320). $\mathrm{Y}$ Ishikawa is thanked for his technical assistance.

\section{References}

Bajjalieh SM \& Scheller RH 1995 The biochemistry of neurotransmitter secretion. Journal of Biological Chemistry 270 1971-1974.

Barroso M, Nelson DS \& Sztul E 1995 Transcytosis-associated protein $(\mathrm{TAP}) / \mathrm{p} 115$ is a general fusion factor required for binding of vesicles to acceptor membranes. PNAS $\mathbf{9 2} 527-531$.

Bradford MM 1976 A rapid and sensitive method for the quantitation of microgram quantities of protein utilizing the principle of protein-dye binding. Analytical Biochemistry 72 248-254.

Burton K 1956 A study of the conditions and mechanism of the diphenylamine reaction for the colorimetric estimation of deoxyribonucleic acid. Biochemical Journal 62 315-323.

Catelli MG, Ramachandran C, Gauthier Y, Legagneux V, Quélard C, Baulieu E-E \& Shyamala G 1989 Developmental regulation of murine mammary-gland $90-\mathrm{kDa}$ heat-shock proteins. Biochemical Journal 258 895-901.

Chomczynski P \& Sacchi N 1987 Single-step method of RNA isolation by acid guanidinium thiocyanate-phenol-chloroform extraction. Analytical Biochemistry 162 156-159.

Collier RJ, McGrath MF, Byatt JC \& Zurfluh LL 1993 Regulation of bovine mammary growth by peptide hormones: involvement of receptors, growth factors and binding proteins. Livestock Production Science 35 21-33.

Feldman DA \& Weinhold PA 1998 Cytidylyltransferase-binding protein is identical to transcytosis-associated protein (TAP/p115) and enhances the lipid activation of cytidylyltransferase. Journal of Biological Chemistry 273 102-109.

Flint DJ \& Knight CH 1997 Interactions of prolactin and growth hormone $(\mathrm{GH})$ in the regulation of mammary gland function and epithelial cell survival. Journal of Mammary Gland Biology and Neoplasia 2 41-48.

Forsyth IA 1983 The endocrinology of lactation. In Biochemistry of Lactation, pp 309-349. Ed TB Mepham. Amsterdam: Elsevier Science Publishers.

Ghosal D, Shappell NW \& Keenan TW 1994 Endoplasmic reticulum lumenal proteins of rat mammary gland. Potential involvement in lipid droplet assembly during lactation. Biochimica et Biophysica Acta $1200175-181$.

Johke T, Hodate K, Hodate Kyo \& Takahashi T 1981 Effects of reserpine and season on plasma prolactin, growth hormone, and lactogenesis in hormonally induced lactation of dairy heifers. Japanese Journal of Zootechnology and Science 52 63-66.

Katoh N, Kira T \& Yuasa A 1993 Protein kinase C substrates and ganglioside inhibitors in bovine mammary nuclei. Journal of Dairy Science 76 3400-3409.

Lascelles AK, Beh KJ, Mukkur TK \& Watson DL 1986 The mucosal immune system with particular reference to ruminant animals. In The Ruminant Immune System in Health and Disease, pp 429-457. Ed WI Morrison. Cambridge: Cambridge University Press.

Lelièvre S, Weaver VM \& Bissell MJ 1996 Extracellular matrix signaling from the cellular membrane skeleton to the nuclear skeleton: a model of gene regulation. Recent Progress in Hormone Research 51 417-432. 
Mather IH \& Keenan TW 1983 Function of endomembranes and the cell surface in the secretion of organic milk constituents. In Biochemistry of Lactation, pp 231-283. Ed TB Mepham. Amsterdam: Elsevier Science Publishers.

Nakamura N, Lowe M, Levine TP, Rabouille C \& Warren G 1997 The vesicle docking protein p115 binds GM130, a cis-Golgi matrix protein, in a mitotically regulated manner. Cell 89 445-455.

Nickerson SC \& Akers RM 1984 Biochemical and ultrastructural aspects of milk synthesis and secretion. International Journal of Biochemistry 16 855-865.

Plath A, Einspanier R, Peters F, Sinowatz F \& Schams D 1997 Expression of transforming growth factors alpha and beta-1 messenger RNA in the bovine mammary gland during different stages of development and lactation. Journal of Endocrinology $\mathbf{1 5 5}$ 501-511.

Raught B, Liao WS-L \& Rosen JM 1995 Developmentally and hormonally regulated CCAAT/enhancer binding protein isoforms influence $\beta$-casein gene expression. Molecular Endocrinology 9 1223-1232.

Rosen JM, Woo SLC \& Comstock JP 1975 Regulation of casein messenger RNA during the development of the rat mammary gland. Biochemistry 14 2895-2903.

Saacke RG \& Heald CW 1974 Cytological aspects of milk formation and secretion. In Lactation, vol 2, pp 147-189. Eds BL Larson \& VR Smith. New York: Academic Press.

Sambrook J, Fritsch EF \& Maniatis T 1989 Molecular Cloning: A Laboratory Manual, 2nd edn. Cold Spring Harbor, New York: Cold Spring Harbor Laboratory Press.

Sapperstein SK, Walter DM, Grosvenor AR, Heuser JE \& Waters MG 1995 p115 is a general vesicular transport factor related to the yeast endoplasmic reticulum to Golgi transport factor Uso1p. PNAS $92522-526$.

Schanbacher FL, Goodman RE \& Talhouk RS 1993 Bovine mammary lactoferrin: implications from messenger ribonucleic acid (mRNA) sequence and regulation contrary to other milk proteins. Journal of Dairy Science 76 3812-3831.
Schneider WC 1957 Determination of nucleic acids in tissues by pentose analysis. Methods in Enzymology 3 680-684.

Seagroves TN, Krnacik S, Raught B, Gay J, Burgess-Beusse B, Darlington GJ \& Rosen JM 1998 C/EBP $\beta$, but not C/EBP $\alpha$, is essential for ductal morphogenesis, lobuloalveolar proliferation, and functional differentiation in the mouse mammary gland. Genes and Development 12 1917-1928.

Silberstein GB, Van Horn K, Shyamala G \& Daniel CW 1994 Essential role of endogenous estrogen in directly stimulating mammary growth demonstrated by implants containing pure antiestrogens. Endocrinology 134 84-90.

Talhouk RS, Bissell MJ \& Werb Z 1992 Coodinated expression of extracellular matrix- degrading proteinases and their inhibitors regulates mammary epithelial function during involution. Journal of Cell Biology 118 1271-1282.

Topper YJ \& Freeman CS 1980 Multiple hormone interactions in the developmental biology of the mammary gland. Physiological Reviews 60 1049-1106.

Vance JE \& Vance DE 1990 The assembly of lipids into lipoproteins during secretion. Experientia 46 560-569.

Watanabe A, Miyamoto T, Katoh N \& Takahashi Y 1997 Effect of stages of lactation on the concentration of a 90-kilodalton heat shock protein in bovine mammary tissue. Journal of Dairy Science $\mathbf{8 0}$ 2372-2379.

Waters MG, Clary DO \& Rothman JE 1992 A novel 115-kD peripheral membrane protein is required for intercisternal transport in the Golgi stack. Journal of Cell Biology 118 1015-1026.

Wooding FBP 1977 Comparative mammary fine structure. Symposia of the Zoological Society of London 41 1-41.

Received 18 August 1999

Revised manuscript received 4 April 2000

Accepted 18 April 2000 